\title{
Profits and votes: Entrepreneurs and the government in Brazilian housing policy
}

\author{
Lucros e votos: os empresários e o governo \\ na politica habitacional brasileira
}

EDNEY CIELICI DIAS*

\begin{abstract}
RESUMO: A política habitacional retomou seu relevo no país com a ascensão do PT ao governo federal, após mais de 20 anos de baixa produção de moradias. Este artigo mostra - por meio da análise de documentos, entrevistas e pesquisa de opinião com empresários que o impulso dessa política pública está inserido no projeto eleitoral petista, baseado no crescimento econômico e na expansão de programas sociais. Verificou-se a confluência de interesses entre o governo Lula (2003-2010) e o empresariado da construção civil - este, interessado em ampliar seus negócios, e aquele, em ampliar a oferta de emprego e o nível de atividade da economia. O ápice desse processo se dá com o lançamento do maior programa de habitação social implantado no país, o Minha Casa, Minha Vida, no qual as construtoras têm papel central na elaboração, viabilização e execução de projetos de moradia social. PALAVRAS-CHAVE: política habitacional; interesses empresariais; definição de agenda; governo Lula.
\end{abstract}

ABSTRACT: After more than twenty years of low housing construction output, the housing policy recovered its momentum in the country with the ascent of the Partido dos Trabalhadores (Workers' Party, PT) to the seat of the federal government. This article demonstrates - through the analysis of documents, interviews and research conducted with businessmen - that the impetus of such a state policy is a part of the PT electoral strategy, which is based on economic growth and the expansion of social programs. The research analyses the dovetailing of interests between the Lula (the Brazilian President from 2003 to 2010) administration and the civil construction business - the latter concerned with expanding its business, and the former with increasing the supply of jobs and the level of economic activity. This process culminated in the launching of the largest social housing program to be implemented in the country. Minha Casa, Minha Vida (My House, My Life), is a project in whose planning building companies played a key role, performing feasibility studies and carrying out social housing projects.

KEYWORDS: public policy; housing policy; business interests; agenda setting; Lula administration. JEL Classification: H53; R31.

\footnotetext{
* PhD student, Departamento de Ciência Política da Universidade de São Paulo, e-mail: edney@uol.com.br
} 


\section{INTRODUCTION}

The close relationship of business sectors with the federal administration of the Workers Party (PT) no longer comes as any surprise to the observers of Brazilian politics. This party with its working class origins had been the cause of apprehension for the elites until the election of its main leader, Luiz Inácio Lula da Silva, as President in 2002. Throughout Lula's terms of office and that of his successor, Dilma Rousseff, business has participated in different groups and councils promoted by the federal government and participated actively in formulating public policies. This article is about the relations during the course of the Lula administration with construction business and their repercussion on housing policy.

There has been a resurgence in the output of Brazilian housing in this new context of convergence between government and private sector interests. Several analyses have pointed to the central role of construction companies in the federal government's principal housing program, My House, My Life (PMCMV). Rare however are studies that have carried out an empirical analysis in relation to the business community with state policies formulated by governments. This article demonstrates empirically the engagement of the private sector in Brazilian housing policy with previously unpublished data with respect to how the construction business regards Lula's government.

This research made from a vast slew of documentation concerning the housing policy of entities which represented the construction industry and the government in addition to housing production indicators. Key figures of the private sector, the government and popular movements for housing were interviewed to obtain information with respect to the most recent period. Empirical material has been complemented by a survey with executives of the building sector.

The next section will deal with the theoretical approach used in analysing the relationship of the government with business. The subsequent section analyses the trajectory of housing policy under the Lula administration. Finally, aspects of the empirical survey will be examined in detail and a brief overview of the results will be presented.

\section{ACTORS AND SOCIAL-DEMOCRATIC LOGIC}

In the institutional literature, the interaction of the actors constrained by institutions constitutes a central element for change. In order to understand these processes, it is, therefore, necessary to open the black box of collective action and identify how the negotiations between the main actors and their coalitions are established. ${ }^{1}$ Reforms in the Brazilian housing policy during the Lula administration

\footnotetext{
${ }^{1}$ In the words of Margaret Weir (2006, p. 175), “[...] established interest definitions and ties are subject to re-negotiation. Such re-negotiations are especially likely in political environments that challenge
} 
enabled a resumption of the production of housing on a large scale in the country (Dias, 2012). These reforms explain the recent performance of the housing market, but which actors supported it? It will be argued in this article that the relationship between the federal Executive with the business sector was central to the drawing up of the housing policy. Using as a reference the decisive role played by the preferences of the coalition in the federal government in the design and implementation of housing policy, the central argument is that the PT's logic of holding onto power was the determining factor in its position on housing.

Three elements of an institutional nature form the structure of this argument:

1. The main decision-making authority in Brazilian housing policy is the federal government. The federal Executive oversees and controls the principle housing funds, sets national guidelines of housing policy, defines the subsidies of the Union General Budget (OGU) for housing and is, furthermore, responsible for the main promoter of housing, the Caixa Econômica Federal. It is, therefore, the main actor concerned with planning and establishing the policy, with the States and municipalities subordinate to it in terms of the supply of resources (Arretche, 2002). ${ }^{2}$

2. The federal Executive is also a privileged locus for the defense of interests and the formulation of housing policy. The Lula administration broadened the channels of access to the federal Executive, by setting up councils and groups. It must be noted that this power determines the norms and regulations which do not need congressional approval. Where legislative production is concerned, Figueiredo and Limongi (2001) demonstrate that Executive Power plays a decisive role. The presidential nature of Brazilian coalition works in practice like a parliamentary democracy in terms of governability and legislative production (Limongi, 2006). Accordingly, the Executive is the prime target of interest groups, as Mancuso (2007) has shown.

3. With respect to effectiveness of access to authority, certain contrasting ele-

existing policies, either directly or indirectly. When the actors are themselves organizations, it is crucial to open the black box of organizational structure and decision-making to understand how groups define their interests and identify potential allies".

${ }^{2}$ In accordance with the Constitution (Article 21, Clause XX), it is the duty of the Union to set guidelines for urban development, including housing, basic sanitation and urban transport, in addition to (Article 23, Clause IX) promoting housing construction programs and the improvement in housing conditions and basic sanitation, in conjunction with the States and municipalities. Few States possess sufficient resources for an independent housing policy - The State of São Paulo is the exception, since it allocates a part of its tax revenues, amount to one percentage point of the share for the provision of housing. The municipalities, in turn, are legally responsible for regulating ground use, urban policies and housing. However, as a rule, funds are not available for carrying an autonomous housing policy. On the other hand, the legal power of the federal Executive concerning urban development, notably regarding the control of ground use and occupation, is small. The City Statute (Estatuto da Cidade) lays down urban policy such as municipal competence, granting the municipality the legal instruments of execution. Therefore, the power of the federal government, although it is central to planning and the control of resources, depends on municipal authority in urban policy. 
ments become apparent when comparing the FHC and Lula administrations. The survey of documentation of civil construction bodies reveals dissatisfaction with the position taken by the FHC government concerning sector-based demand - "dialogue" existed, but rarely translated into coordinated policies between the government and the private sector. Lula's government, on the other hand, showed itself to be receptive to propositions by business.

According to Diniz (2009), the Lula administration resumed - albeit modifying - the former tradition of coordinating between the private and public sectors, between the civil and State sectors, within specific bodies of the State's apparatus. The creation of these groups formalizes direct channels between government and businesspeople which dispenses with Congress as intermediary. Besides more formalized fields of activity, representatives of business sectors find channels open to them for discussion in the ministries and in the Presidency of Republic itself. ${ }^{3}$

This position in relation to the business community is directly related to PT's electoral strategy. The party had consolidated itself as an electoral force since the 1980s, but always as a secondary force in its bids for the presidency. For the 2002 election, Lula was in no doubt as to the need to establish broader alliances, even if this involved alliances with parties on the right. The choice was between winning or not winning; this implied a program which was not hostile to capital (Singer, 2010; Samuels, 2004). ${ }^{4}$

In order to reach the federal government and set up a coherent political project, PT follows a script similar to that of European social democracy, such as the one formulated by Adam Przeworski (1985, [1991]). The worker-based party, by abandoning the revolutionary path and taking part in elections, garnered a majority in order to get into power, allying itself with parties on the right. Once in power, following this script, the party sought to attend to the interests of its bases with a policy of economic growth and the generation of employment, which is why it formed alliances with the business sector.

In case of PT, the strategy is to generate jobs, income and tax revenue, essential elements for an electoral base originally constituted by workers with the addition, throughout its mandates, of broader segments who benefitted from social programs

\footnotetext{
${ }^{3}$ This question was discussed in the course of interviews on this research, in the comparison between the mandates of FHC and Lula. According to Sérgio Watanabe, president of the Construction Industry Trade Union of São Paulo (Sinduscon-SP), "The PT has now heard and adopted ideas which it considered worthwhile, as opposed to FHC affiliates". For José Carlos Martins, vice-president of the Brazilian Chamber of Industry and Construction (CBIC), "in the FHC government, the leaders cloistered themselves and there is no place for this in today's world. The Lula government introduced a trade-union element - the negotiation table."

${ }^{4}$ A source for apprehending aspects of this project is the film "Entreatos", by the director João Moreira Salles, which documents what takes place behind the scenes of a PT candidate in the presidential election of 2002. It's possible to hear Lula himself and see at work the strategy used to win the election, drawn up at some remove from the preferences of the more radical wing of the party. Once he takes power, Lula works out a role for these radicals, as the party's “critical conscience", subordinated to the realistic plan of the government, the latter gestated at the Citizen Institute and not in party bodies, as Samuels (2004) and Maricato (2011) recount.
} 
(Singer, 2009). Within the social- democratic mechanism in the ascendant and in order to maintain power, the party with working class roots put itself forward as a guarantor of capitalism in the course of its accumulation of economic activity and as Keynesianism was transformed into social-democratic economic policy (Przeworski, 1991 [1985]; Schmitter, 1974)..$^{5}$

Therefore, as from 2002, an alliance was formed in Brazil of actors whose preferences had apparently hitherto been antagonistic, that is to say, PT leaderships and business. By all appearances paradoxical, it was not unprecedented when formulating public policies that actors with different interests should agree with a particular policy objective for different reasons, according to Lindblom (1959). Lula's plan for government envisioned housing, and this became an integral part of his logic in terms of retaining power. Civil construction business, in its turn, sought conditions favourable towards business. In other words, the government had its eye on votes, with the attention of business focused on profits.

The construction sector, by nature, generates a high volume of jobs and demand for housing and infrastructure projects is great in Brazil (Fundação Getulio Vargas, 2006; Ernst\&Young, 2008). During the PT administration, civil construction businessmen enjoyed a privileged position during at three junctures when it came to setting the agenda:

- In the quest for resuming economic growth by the government at the beginning of its first mandate, in which the demands from the private sector for legal tenure with regards to the real estate market and for the investment of funding resources in housing were envisioned (2003-2004). Housing served, therefore, as an incentive for economic activity. ${ }^{6}$

- In 2007, with the launching of the far-reaching infrastructure program at the beginning of his second mandate, the Growth Acceleration Program (PAC), which involved social housing projects. The purpose of this was to stimulate investment. It considered the stimulation of investment and housing was part of the solution, with plans to urbanize slums. The 2006 presidential election saw the formation of a broad coalition within the construction sector around a project of a similar nature to that of the PAC.

- In the cauldron of anti-cyclical policies, countering the effects of the world economic crisis, into which the PMCMV (2008-2009) was thrown, housing came to the fore as a solution, receiving massive state investment in social programs. The project was one defended by the civil construction sector and adopted and broadened by the office of the President of the Republic.

The following sections analyse and qualify these three stages for setting the agenda.

\footnotetext{
${ }^{5}$ Yet not only social democracy is emphasized. It is sufficient to remember Roosevelt's New Deal, which was not a total social democracy.

${ }^{6}$ In fact, this is an important dimension in large-scale housing programs. Arretche (1990) showed that this had been the emphasis in large-scale initiatives in Sweden and the United States, of a Keynesian nature, and also in the Brazil of the economic "miracle".
} 


\section{THE TRAJECTORY OF HOUSING POLICY DURING THE LULA ADMINISTRATION}

The rebirth, so to speak, of the housing sector occurred 20 years after the closure of the National Housing Bank (BNH) in 1986. If the resurgence of the housing production to pre-crisis levels was improbable during the years following its closure - due to factors such as high inflation, low economic growth and institutional fragmentation -, it seems reasonable to assume that it occurred after the stabilization of the Brazilian economy, with the introduction of the Real Plan (1994). It was only after a long period, however, that this was to take place.

The electoral banner of stabilizing the economy had been consolidated and had exhausted itself in the eight years of Fernando Henrique Cardoso (PSDB). This last head of government had planned to set Brazil on the road to economic growth in his second presidential mandate (1999-2002). However, his plans were undermined by electricity supply problems and by international crises, which severely affected emerging countries (Baer, 2009). Lula came to power with the prospect of creating an agenda for the generation of jobs and income, while respecting the conditions for macroeconomic stability that had been established by his predecessor - in this sense it was a calculated strategy of discontinuity.

The PT's economic growth project had already been put into practice during Lula's first mandate. The application of the proposal took place by means of reforms, applied on two complementary fronts of state policy: in the recovery of investment of housing funds - with measures of juridical security of direct concern to the real estate sector - and in the federal-style articulation of housing policy in the light of the provisions of the Estatuto das Cidades (statute of cities) and of the establishment of a system of social housing in the country, in an agenda linked directly to housing movements and party militancy (Dias, 2012).

According to Maricato (2005), Lula's government sought to put into practice a new paradigm of housing policy. The project was set up at the Cidadania Institute, created by Lula and his most intimate circle with a view to putting together a program of government in the hope of winning the 2002 elections (Samuels, 2004). The plan was consolidated in the Projeto Moradia (Housing Project), a document that comprised a broad raft of proposals for a housing policy. ${ }^{7}$ The link between housing policy and economic growth featured in Projeto Moradia. ${ }^{8}$

\footnotetext{
${ }^{7}$ According to Maricato (2011), Project Moradia was directly monitored by Lula and sponsored by the Djalma Guimarães Foundation and Bancoop (Bankers Housing Cooperative). "It was drawn up by a team of experts, parliamentarians and social leaders after listening to the representatives of various social sectors" (p. 7). In an interview for this survey, Evaniza Rodrigues, an advisor for the Caixa Econômica Federal and leader of the National Union of Popular Housing, opines that "Project Moradia represented the convergence of political actions and visions in the context of experiences pre-dating the housing movements".

${ }^{8}$ Which can be verified in the following passage: "Massive investments in housing construction at the same time as in urban reconstruction were, above all, seen as a powerful tool in helping to break the
} 
The project was aimed at broadening the housing market, making it the duty of the State to allocate subsidies directly to housing financing. The proposal to complement financing through the use of subsidies had been defended from at least the mid-1990s by private sector bodies, in accordance with this research it was verified in documents pertaining to the construction industry. The Ministry of Finance wished to activate the real estate market as a means of reviving the economy and, consequently, sought to heed the voices of the major segments involved. This positioning by the PT was in marked contrast to the FHC administration:

"Throughout the world, civil construction was the driving force behind growth. In Brazil, this was the brake. Such was the view of Minister of Finance, Antonio Palocci. He had the good sense to ask what was needed to make the sector grow" (José Carlos Martins, vice-president of the Brazilian Chamber of Industry and Construction - CBIC, during an interview for this research).

During these discussions, the Ministry of Finance became convinced of the importance of winning back housing credit for the economy at that time. Law 10.931, put forward by the Executive at the beginning of 2004, and added to a bill which had been going through Congress since 1999, was passed in August of the same year. The strategic importance of the law is stressed by none other than minister of Finance, Antonio Palocci:

"People should not only be thinking about so-called structural reforms, but also the so-called micro-economic reforms, which have great potential to ease the basic bottlenecks at the basis of our economic development [...] Bringing about the reform for civil construction, with Law no. 10.931 of 2004, the Lula government and Congress revived the real estate sector" (Palocci, 2010).

Banks lost at a faster rate benefits that had been granted in previous years, due to the restructuring of the banking system, and were obliged to comply with investment targets in real estate. Resolution 460 of FGTS (Social Housing Fund) in 2004 made it more favorable for the fund to grant subsidies directly in order to provide financing for lower income families, a historical demand from sectors of the housing policy adherents. The fund thus became more markedly involved in social policy. In addition, the volume of FGTS resources for housing grew sharply due to the influence of the federal government.

The balance of real estate credit within the Country stood at $\mathrm{R} \$ 25.7$ billion in 2004, the year in which Law 10.931 was approved and complementary measures

vicious stranglehold of stagnation, unemployment and misery so prevalent in Brazil. The multiplying effects on the economy and the social question are easily measurable when seen against the importance of the construction sector within the national economic framework" (Instituto Cidadania, 2000, p. 16). 
taken for the expansion of credit. From then on, it spiralled, reaching R $\$ 277$ billion in 2012, that is to say, more than ten times the amount recorded in $2004 .{ }^{9}$ As far as housing funds are concerned, the SBPE (savings) it loaned R 2.2 billion for housing in 2003 - this amount jumped to $\mathrm{R} \$ 82.7$ billion in 2012, that is to say, the initial figure was multiplied by 37 for the period. The FGTS, in its turn, invested $\mathrm{R} \$ 3.8$ billion in housing in 2003 and $\mathrm{R} \$ 36.0$ billion in 2012, i.e., the multiplication of the first amount by nine. ${ }^{10}$

With the resumption of housing production, in 2006 a broad alliance of the construction production chain came about, involving 136 sector entities, with the National Construction Union (UNC), with the aim of submitting to the presidential candidates of the Republic proposals for the resumption of investment in infrastructure and increased investments in housing (Dias, 2012). With a stronger economy at the end of Lula's first mandate, ${ }^{11}$ there were signs in the ministries of mobilization of investment, which would be fleshed out in 2007, in the course of his new mandate. At the beginning of this year, the agenda was characterized by investments in infrastructure that would raise economic growth to a new level. It was at this time that the PAC came into being, a strong signal of investments by the public sector and state enterprises, attending to a large degree, to the demands of the UNC (Dias, 2012). As for investments in housing concerning the PAC, the priority of the government, in tandem with the National Housing Policy, was investment in the urbanization of slums.

Economic stimulation had always been the driving force behind the Lula Government's housing policy, whether in terms of defining the regulatory framework of the real estate sector (2004), or with the PAC (2007). The PMCMV, launched in 2009 in the midst of the global financial crisis, represents the quintessence of the logic behind the reforms which led to resumption of large-scale housing production in Brazil. The government's objective was not to let the social-development project sink on the eve of the general elections, which took place in 2010.

The Ministry of Cities, in the process of sharing the federal administration with the coalition in support of the government in the National Congress, had been handed to the Progressive Party (PP) in 2005, but the kernel of the housing policy remained under the control of the PT directly linked to the Government palace, led by Dilma Rousseff herself and to the Presidency of the Republic. The MCMV was co-ordinated by the highest echelon of federal government with the country's main construction firms, ${ }^{12}$ the CBIC (representative of small and medi-

\footnotetext{
${ }^{9}$ Source: Ipeadata, based on Central Bank data, referring to operations carried out by natural persons and housing co-operatives.

${ }^{10}$ Source: Brazilian Chamber of Industry and Construction and Construdata site.

${ }^{11}$ After modest growth in GDP in the first year of Lula's mandate $(1.1 \%)$, the economy witnessed high rates of expansion, witnessing at the close of Lula's first mandate an annual average growth of $3.5 \%$ according to data supplied by the Ministry of Works (www.fazenda.gov.br).

${ }^{12}$ Maricato (2011) speaks about 11 construction firms, but there are those who claim there were 13.
} 
um-sized construction companies) and also with leaders of the housing movement. The government envisaged an alternative of rapid investment in housing, even if this took place outside of the institutional context defended by PT militants. ${ }^{13}$ The front line of the government's housing policy became the construction of social housing based on projects proposed, made feasible, and carried out by construction companies with direct subsidies to the families. In its first phase, announced in 2009, the program's goal was the construction of 1 million residential units and provision of R \$ 34 billion in subsidies; in its second stage, announced in 2010, the scope of the objective expanded to over 2 million units, with another R $\$ 72.6$ billion in subsidies (Dias, 2012). ${ }^{14}$

Putting the program into practice meant providing conditions for implementation to private companies, which would not be subjected to the deliberations of government controlling departments and to the necessity of a bidding process. Contracting for the works by PAC were slow and problematic and did not serve the objective of obtaining immediate results..$^{15}$ The institutional outline of the Fundo de Arrendamento Residencial (FAR, residential leasehold fund), of the residential leasehold program, made it possible for resources to be passed on directly to the companies involved. The PMCMV was set up bearing in mind the combination of opportunity factors, as summarised in Chart 1.

The Caixa Econômica Federal, apart from its traditional function as financier it became the major facilitator of projects, responsible for coordinating public and private actions in business undertakings, being the program's de facto grand ex-

\footnotetext{
Major companies of the sector, such as Odenbrecht, Gafisa and Rossi, were present. However, the implementation of the PMCMV revealed the importance of widespread activity of medium-sized and small construction companies. For this reason the role of the major construction companies in the PMSMV must be relativised.
}

${ }^{13}$ The choice of program was met with criticism from the policy community, specifically from academic circles linked to social movements and to technical advisory boards. "Businessmen posted their proposals on PMCMV, which had for a long time been rehearsed directly to the government. Thus the government attended to different interests, while a more systemic vision of Urban and Metropolitan politics was forgotten" (Maricato, 2011, p. 84). According to Bonduki (2009), upon launching the program before presenting the National Habitation Plan (PlanHab), the government had lost the opportunity to show how an anticyclical activity could be coordinated with a structural strategy. The author highlights the tension in formulating the program: "The intervention of the National Housing Secretariat, backed by the process of drawing up a National Housing Plan enabled this anti-cyclical activity to garner some social content, far short of what would have been possible if the strategy of the PlanHab were a standard for emergency measures which needed to be taken".

${ }^{14}$ The program caters to families whose income is the equivalent to 10 minimum salaries and containing staggered subsidies, covered by FGTS funds and the Budget of the Union, and families with an income of up to 3 minimum salaries enjoying a subsidy of up to $90 \%$. This percentage is staggered up to a band of 6 minimum salaries, above which there were no direct subsidies. The quantity of units and the volume of subsidies have no parallel in Brazilian housing policy.

${ }^{15}$ This evaluation was obtained by means of interviews, or example, with Inês Magalhães, national secretary of Housing, Dyogo Henrique de Oliveira, deputy executive secretary of Economic Policy, and several statements made by businessmen and housing movements. 
ecutive agent. In other words, the bank became responsible for bringing about a coupling between the public and private sectors in proposing, rendering feasible and implementation of social housing projects. In this context, there occurs a process of apprenticeship involving units of the Federation, construction companies and the financial institution (Dias, 2012).

\section{Chart 1: PMCMV ChoiceFactors}

\section{Conditioning political factors}

The international financial crisis might compromise the development of a federal government project of a social-democratic nature.

This would put at risk the 2010 elections, involving the election of a president, and governors, renewal of the Chamber and to two thirds of the Senate.

The government, because of its social-democratic nature, was prone, in true Keynesian fashion, to a more interventionist stance in economic affairs.

The government had the power to approve in Congress a high-cost program, such as housing subsidies.

\section{Government preference for the policy}

The government had a preference for a policy of expenditure with an economic impact of a social nature, out of which housing grew.

The urbanization of the slums as part of the PAC program was a slow process - for an anticyclical policy swift implementation was of the essence, which FAR would make possible.

The construction of new housing units complemented the activities of the PAC and was target of demands for civil construction by social movements.

\section{Conditioning economic factors}

Residential construction generates a high number of jobs.

It has a high multiplying effect on the remaining areas of the economy.

A housing construction policy has an effect on the entire country.

It is essentially a domestic policy with national input.

There was strong demand for housing at all social levels.

Building companies could rapidly increase the housing supply.

Credit was made available and families were only slightly indebted.

Source: Produced by the author, based on interviews with the private sector and participants of the process within the Treasury, Ministry of Cities and the Caixa Econômica Federal.

The political housing trajectory in Lula's government, drawn up on the basis of documentary research and interviews with key persons, reveals the economic and electoral motivation which from housing reforms, by analogy with the social- 
democratic mechanism outlined by Przeworski (1985, [1991]). The PMCMV, in its turn, arises as the product of the Workers Party electoral project and quintessential example of this mechanism.

\section{DOVETAILING OF GOVERNMENT - BUSINESS INTERESTS}

The factors influencing housing policy in Lula's government were analysed based on interviews, production indicators and documentary research. The detailed analysis of the documents over time, in its turn, offers a more nuanced view of the strong relationship of the business community and the federal administrations, which helps to understand the process of confluence of government-business interests. Among the documents considered for this survey, the most distinguished were the Annual Reports of the Brazilian Chamber of Industry and Construction (CBIC) - a national body representing the sector - and opinion articles by the Syndicate of Industry and Civil Construction for the State of São Paulo (Sinduscon-SP), the main state syndicate to represent building companies. This documentation permitted the detailed evaluation of the position of construction companies over a period of 16 years, comprehensively covering the mandates of FHC (1995-2002) and Lula (2003-2010).

With the launching of the Real Plan (1994), there was a marked expectation among these entities for a recovery in economic growth, with the sector playing the leading role. As far as housing policies were concerned, the CBIC expressed an idea that would subsequently be difficult to defend in the PT's Projeto Moradia.

"Subsidies will definitely need to be granted to the lowest income groups whether allocating resources for which reimbursement is not mandatory or at a favorable or zero interest rate, or granting exemptions, or awarding fiscal or para-fiscal privileges" (CBIC, Considerations regarding the Policies necessary for the revival of the Construction Business, January 1995, without page numeration). ${ }^{16}$

In December 2001, the CBIC had thrown in the towel concerning attempts to obtain from the FHC government an agenda committed to investments. During the full term of the PSDB government no study was carried out for a project of economic growth within a context favourable to the sector, which was instead overshadowed by an agenda geared towards safeguarding stability. In its annual balance of 2002, the CBIC aligned itself with proposals by the Lula government for Brazilian civil construction, as well as to the expansion of social policies:

\footnotetext{
${ }^{16}$ Until recently, CBIC documents were available on the body's Internet webpage, which is now no longer the case. If needed, the required documents may be consulted, I think, at CBIC itself or even by contacting this author (edney@uol.com.br).
} 
"The platform of the Lula government was based on a new inclusion-oriented economic development model [...] which is why a greater surge was expected for the sector in the medium-term, given that the new Government had chosen civil construction as one of the mainstays for jobs creation and the revival of the economy, as well as a standby, in order to achieve greater social inclusion in Brazil (Analysis by the $\mathrm{Na}$ tional Economy and Civil Construction in 2002 and Prospects for 2003, December 2002, p. 16).

The analysis by Sinduscon-SP reveals a common agenda for demands in terms of a resumption of economic growth and for housing. The body had been expressing its opinion on a weekly basis since 1994 in an advertising supplement entitled Janela (window) in the daily newspaper Folha de S.Paulo. These texts were examined from their inception until the end of 2010, in such a manner as to obtain a detailed perspective of the positioning of the syndicate in relation to housing poli$\mathrm{cy}$ and the economic situation during the FHC and Lula administrations.

Based on the collection of Sinduscon-SP publications in the newspaper Folha de S.Paulo, tabulations were drawn up regarding the presidential mandates, ${ }^{17}$ that is to say, the two administrations of both FHC and Lula. Each of the 822 articles analysed was tabulated in accordance with its subject. Also considered was the general context for the ratings of each document.

$i$. Negative ratings refer to the disapproval or statement of the negative consequences of a measured datum, as well as analyses of negative contexts.

ii. Positive ratings are the opposite of negative cases.

iii. Strategic ratings, in turn, refer to articles that argue a subject by way of analysis, or even a proposal, without it being linked to a positive or negative rating.

The topic of the economic situation is one of the most frequent among the 14 topic $^{18}$ recorded during FHC 1 and Lula 2 - which is explained by the predominance of subjects linked to the establishment of the Real Plan, in the first case, and the emphasis given to policies combating the effects of the international crisis, in the second. The subject of federal housing is the most frequent during the FHC 2 and Lula mandates.

Graph 1 presents the ratings from a combination of perspectives. It concerns a topic which subsumes sub-topics, such as economic growth, sector growth, con-

\footnotetext{
${ }^{17}$ This survey was conducted into the archives of the syndicate, which facilitated the work. Texts of articles published in Janela are also available in the online Folha de S.Paulo collection at <http://acervo. folha.com.br/>. For various reasons $4.2 \%$ of Janela articles were not inputted, that is to say, 36 out of the 858 documents. This does not, however, compromise the analysis.

${ }^{18}$ The topics are the following: economic situation or perspective; federal housing; bidding, jobs, public works; state housing, municipal housing, and other; technology and quality; taxation; politics; environment; Judiciary; urban policy; prices and trade unions.
} 
trol of inflation and investments, which refer to the business prospects for the sector. In order to understand the assessments of economic situations, it is necessary to bear in mind that since economic stabilization, created thanks to the Real Plan, the main aspiration of both Sinduscon-SP as well as that of the CBIC, was the increase in investment in infrastructure and housing.

Graph 1: Themes on the economic situation: presidential mandates compared by type of assessment (\%) and the absolute number of occurrences

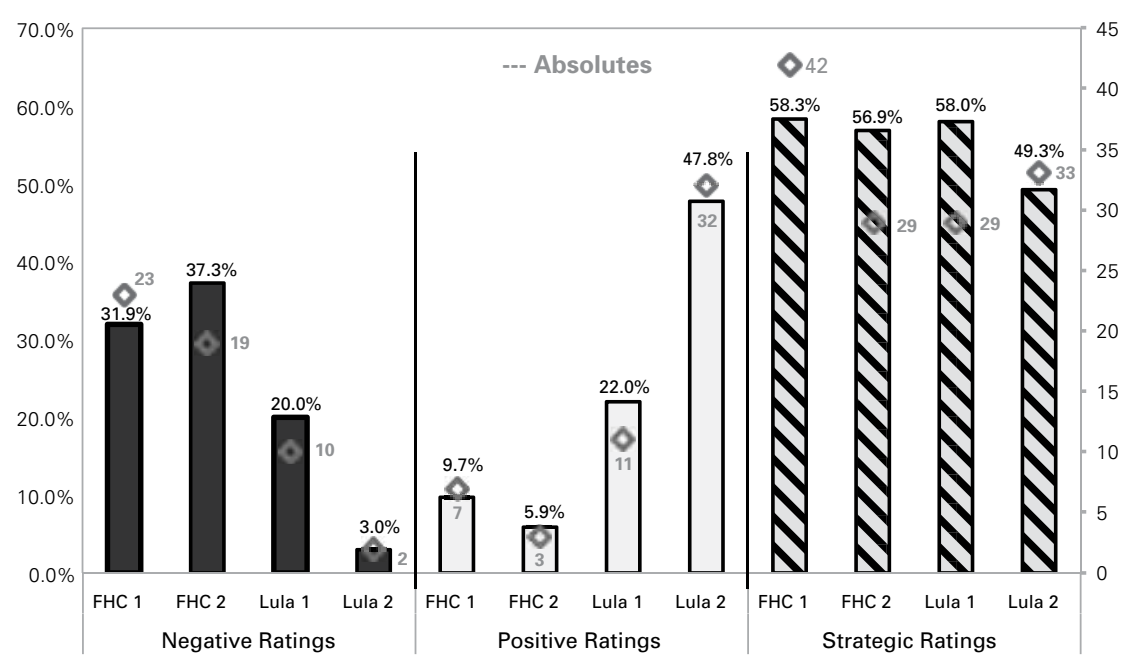

Source: Produced by the author, based on articles written by Sinduscon-SP for the the newspaper.

Presidential mandates are compared in the Graph 1 by assessment type - thus, for example, negative evaluations covering the four presidential periods have been grouped together in such a way as to enable an immediate comparison. Types of evaluation (negative, positive and strategic) come to a total of $100 \%$ for each mandate. FHC's first mandate, for example, garnered $31.9 \%$ of negative assessments on the subject of the economic situation, $9.7 \%$ positive and $58.3 \%$ strategic.

On the other hand, what was remarkable was the high number of negative ratings with respect to the FHC government, with percentages of $31.9 \%$ and $37.3 \%$ for the first and second mandates, respectively. During FHC1, these evaluations where mainly due to the frustration associated with low national and sector growth. The period corresponding to FHC 2, on the other hand, saw the initiative for an economic take-off aborted in 2001 because of power outages and the unfavourable international economic situation.

With regards to the Lula administrations, the first was fraught with uncertainty, notably at the beginning, when the economy found itself in the doldrums. This was reflected in $20 \%$ negative evaluations - this percentage falling to a mere $3 \%$ during his second mandate, which witnessed a strong recovery in growth, with a greater alignment between sector and government. 
With respect to the positive ratings, these were more pronounced during the Lula government, with $22.0 \%$ and $47.8 \%$, for the first and second mandates, respectively - with the highest percentage for FHC occurring during the first mandate with $9.7 \%$. Lula's high percentage when already in his first mandate was due to measures involving co-operation among the different sectors of the economy and a recovery in business activity, with the generation of jobs and income associated with programs designed to combat social inequality. The number of positive evaluations for the period corresponding to Lula's second term in office is particularly important because it refers to the period covering an international crisis - in other words, measures of Keynesian inspiration pleased the construction sector, which became a privileged dynamic element in the economy from 2008-2009. ${ }^{19}$

With respect to opinions regarding federal housing, the contrasts between the FHC and Lula governments are even more pronounced, as can be seen in Graph 2. Firstly, percentages higher than $55 \%$ of negative ratings regarding this question during both FHC's terms of office, which is expressed by the frustration at the low volume of resources allocated to housing and by the perception that this public policy had not been receiving due attention by the federal government. In contrast, the negative ratings of the Lula government are of a far lower caliber $-6.2 \%$ during the first mandate and none at all in the second.

In fact, positive ratings, which had translated into low percentages during the FHC mandates $(10.5 \%$ and $4.8 \%$ for the first and second term of office, respectively), had become quite frequent during the Lula mandates, with $23.1 \%$ in the first and $52.8 \%$ in the second.

The analysis of the documentation of the two principle entities of construction companies over the four federal administrations reveals a growing process of reversal of expectations throughout the FHC mandates, since no good scenario had materialised which favoured investment in housing and infrastructure. As far as Lula's government is concerned, entities displayed enthusiasm towards the proposals to recover present housing in the presidential program of 2002, despite doubts regarding the direction the Worker's Party might take. In the course of time a growing confluence of interests between the construction entities and the Lula administration, which reached a climax in 2010 - which is reflected in the positive evaluations and in the confidence in the government which were expressed in the documents.

Did this clear and progressive strengthening of ties between the Lula Administration and the main construction entities reflect the position of the construction companies? In order to have an idea of this, a questionnaire was distributed to participants on the occasion of the $83^{\circ}$ National Gathering of the Civil Construction Industry (Enic), which took place on the $10^{\text {th }}, 11^{\text {th }}$, and $12^{\text {th }}$ of August 2011 in São Paulo. The participants were representatives of the main sector bodies, businessmen,

\footnotetext{
${ }^{19}$ While the economy grew by close to zero in 2009, GDP of civil construction posted growth of $8.3 \%$ in real terms (FGV calculus based on IBGE data). The expansion of civil construction, in its turn, was driven by the activity of building companies, which registered a growth rate of $18.5 \%$. In other words, sector-based activity prevented the country from entering a recession, creating the conditions for an economic recovery within a short period of time.
} 
Graph 2: Themes of federal housing: presidential mandates compared by type of ratings (\%) and absolute number of occurrences

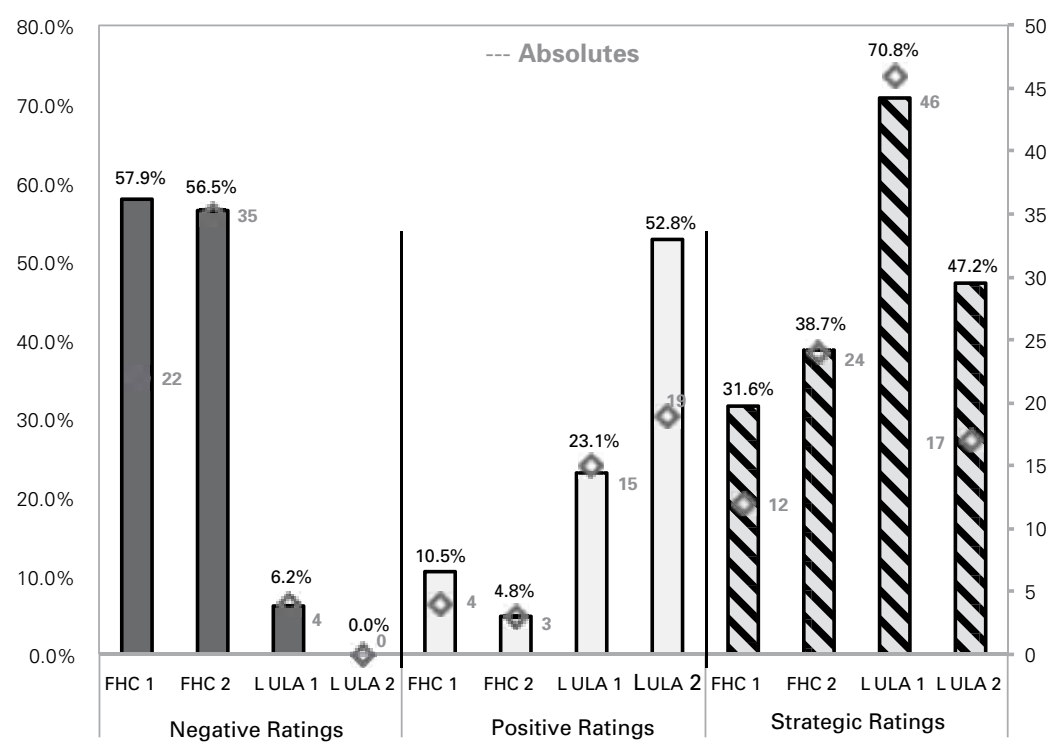

Source: Produced by the author, based on newspaper articles written by Sinduscon-SP.

executives or sector experts - a group that was well-informed regarding the areas in which they were active. The 128 executives who were prepared to answer the questions participated on housing and infrastructure panels for the event. ${ }^{20}$

Firstly, $95.3 \%$ of those who responded to the survey considered dialogue with the government to be important for sound performance of the sector. Dialogue, in this case, means the discussion of public policies, discussed with business entities and the predictability of actions on the part of the federal government. It was also asked whether the federal government had heeded the sector more in recent years, which was reflected in the improved business outlook: for $80.5 \%$ of the respondents the answer was positive - with only $10.9 \%$ responding negatively and $8.6 \%$ don't know's. For $74.2 \%$ of those canvassed, the positive business outlook and signals that public policy had favoured the joint action of the members of the production chain of construction.

Questions were asked regarding the positive role of the social programs in general, with respect to the business prospects for the interviewee: $77.3 \%$ agreed

\footnotetext{
${ }^{20}$ The executives participating on the housing and infrastructure panels received the questionnaire, distributed by the organizers of the event in which 500 people participated over the three days, yet of whom only a part sat on panels of housing and infrastructure. There was a geographical distribution of executives, consistent with the distribution of companies, according to the Construction Industry's An annual Research (Paic-IBGE, 2009). The research was conceived by this author and enjoyed the collaboration of the economist Ana Maria Castelo (FGV-Ibre) in discussing the data, and the economist Fernando Garcia de Freitas in entering the data and overall appraisal. For more details, see Dias (2012).
} 
with the importance of these programs for companies, as opposed to only $12.5 \%$ of those who disagreed. Generally speaking, recent social policies are seen as important elements for the growth of the domestic market. Finally, questions were asked concerning the effect of large-scale government investment programs on the business outlook of the respondents. The PAC was considered important for $71.1 \%$ of those interviewed. A total of $67.2 \%$ considered the PMSMV important or very important for the business outlook, with $20.3 \%$ attributing to it a low-key role. When questioned on the importance of state investments in general, the percentage of respondents who considered these to be important reached $87.5 \%$ as against only $6.3 \%$ who considered these of little importance (Dias, 2012).

By way of summary, there is evidence that the construction executives were of one mind with the entities representing them, according to the analysis carried out by CBIC and Sinduscon-SP.

\section{FINAL CONSIDERATIONS}

The relationship of the PT governments with business circles is a live issue, but one lacking in empirical research. This article empirically analysed the engagement of the private sector in Brazilian housing policies, with data presented for the first time regarding how the Lula government was perceived by civil construction business community. It was observed that this public policy was conditioned by the PT electoral strategy, which involved the alliance of the party with business.

The data have shown the confluence of interests between the PT government and the civil construction business community over the years, within a virtuous context of public policy expansion and obtaining results in terms of expanding the supply of housing, an increase in the level of employment and the provision of social housing.

The advent of the PT with an electoral manifesto based on an increase in jobs and income, including construction businessmen with a direct interest in expanding the housing market, was sufficiently strong to marginalize the proposals for housing from the Party's militant wing. The frontline for the government's housing policies became, after the PMCMV, the construction of social housing, studied and carried out by construction companies with direct subsidies for families.

\section{REFERENCES}

Arretche, M. (1990) “Estado e mercado na provisão habitacional: três modelos de políticas”. Dissertação (Mestrado) - Instituto de Filosofia e Ciências Humanas da Universidade de Campinas.

Arretche, M. (2002) "Federalismo e relações intergovernamentais no Brasil: A reforma de programas sociais". Dados, v. 45, n. 3, pp. 431-458.

Baer, W. (2009) A Economia Brasileira. São Paulo: Nobel.

Bonduki, N. (2009) “Do Projeto Moradia ao Minha Casa, Minha Vida”. Teoria e Debate, 82.

Dias, E. C. (2012) “Do Plano Real ao Programa Minha Casa, Minha Vida: negócios, votos e as refor- 
mas da habitação". Dissertação (Mestrado) - Faculdade de Filosofia, Letras e Ciências Humanas da Universidade de São Paulo.

Diniz, E. (2009) “Estado, variedades de capitalismo e desenvolvimento em países emergentes.” Seminário Internacional INCT-PPED: Promovendo Respostas à Globalização. Disponível em: <http:// www.ideiad.com.br/seminariointernacional/>. Acesso em: set. 2010.

Ernst\&Young. (2008) Brasil Sustentável: Potencialidades do Mercado Habitacional. São Paulo: EYGM Limited.

Figueiredo, A.; Limongi, F. (2001) Executivo e Legislativo na Nova Ordem Constitucional. Rio de Janeiro: FGV/Fapesp.

Fundação Getulio Vargas (2006) A Construção do desenvolvimento sustentado - A importância da construção na vida econômica e social do país, FGV Projetos. Disponível em: <http://www.fiesp. com.br/comite/comcic/pdf/Estudo \%20da \%20UNC\%20em\%20português\%20-\%202\% $\% 20$ versão.pdf >. Acesso em: jun. 2012.

Garcia, F.; Castelo, A. M. (1997) O Sistema Financeiro da Habitação: Problemas Estruturais e Diretrizes para uma Reforma. São Paulo: Sinduscon-SP.

Instituto Cidadania. (2000) Projeto Moradia. São Paulo: Instituto de Cidadania.

Limongi, F. (2006) "Presidencialismo, coalizão partidária e processo decisório. Novos Estudos Cebrap, 76.

Lindblom, C. E. (1959) "The "science" of muddling through". Public Admininstration Review, 19, p. 79-88.

Mancuso, W. P. (2007) O Lobby da Indústria no Congresso Nacional. São Paulo: Humanitas/Edusp/ Fapesp.

Maricato, E. (2005) “A nova política nacional de habitação”. Valor, edição de 24 de novembro.

Maricato, Ermínia (2011) O Impasse da Política Urbana no Brasil. Petrópolis: Vozes.

Palocci, A. (2010) "Reformar para crescer". Jornal Folha de S. Paulo, 27 de junho.

Przeworski, A. (1985) "Social democracy as historical phenomenon". In Capitalism and Social Democracy. Cambridge University Press, 1985.

Samuels, D. (2004) "From socialism to social democracy". Comparative Political Studies, v. 37, n. 9.

Singer, A. (2009) "Raízes sociais e ideológicas do Lulismo". Novos Estudos Cebrap, 85.

Singer, A. (2010) "A segunda alma do Partido dos Trabalhadores". Novos Estudos Cebrap, 88.

Schmitter, P. C. (1974) "The new corporatism: social and political structures in the Iberian world". The Review of Politics, v. 36, n. 1, p. 85-131.

Weir, M. (2006) "When does politics create policy? The organizational politics of change". In Shapiro, Ian, Skowronek, Stephen, and Daniel Galvin (eds.). Rethinking Political Institutions. New York: New York University Press. 